ROCZNIKI NAUK SPOŁECZNYCH

Tom 11(47), numer $2 \quad-\quad 2019$

DOI: http://dx.doi.org/10.18290/rns.2019.47.2-5

VICTOR MOCANU

LUDMILA MALCOCI

ION MOCANU

\title{
MIDDLE-CLASS FORMATIVE FACTORS \\ IN THE MOLDOVAN CONTEMPORARY SOCIETY
}

\section{INTRODUCTION}

The relevance of research in social stratification is undeniable considering the conditions of socio-economic and political changes that occurred in Moldova with the signing of the EU association agreement. The studies conducted over the past 20 years show significant changes in the social structure of the Moldovan population. The transition to market economy influenced the formation of new social groups, which differ by size of income, property, education, political and economic power, and social status. The emergence of new social groups requires thorough and complex studies to identify their determinants, size, essential characteristics, the system of values, as well as their economic, social and political situation. The research is important also from the practical and methodological points of view. The research data will serve as a base line for determination of the size of different social strata in Moldova and the developed research methodology will be used for further research in the field.

Victor Mocanu, PhD, associate professor, director of the Sociology and Social Psychology Centre, Institute of Legal and Political Research, Academy of Sciences of Moldova (ASM); address for correspondence: Bd. Ștefan cel Mare si Sfint, 1, Chișinău, MD-2001, Moldova; e-mail: atitudinemd@gmail.com.

Ludmila Malcoci, PhD, Hab, professor researcher, Sociology and Social Psychology Centre, Institute of Legal and Political Research, ASM; e-mail: ludmilamalcoci@gmail.com. 
THE THEORETICAL AND METHODOLOGICAL APPROACH FOR MEASURING THE MIDDLE CLASS

The research was based on an analysis of social theories related to social stratification and social classes, including the Marxist theory, ${ }^{1}$ Weber's theory, ${ }^{2}$ the functionalists' theory (Kingsley Davis, Wilbert Moore, Talcott Parsons, Bernard Barber), Pitirim Sorokin's theory on social mobility, ${ }^{3}$ as well as the theory of social class division developed by Anthony Giddens. ${ }^{4}$ Based on those theories, we concluded that social stratification is the distribution of people in groups based on their occupation and income, wealth and social status, or social and political power. Sorokin identified at least three forms of stratification: 1) economical stratification (differences of property, income and lifestyle, division into the rich and poor), 2) political stratification (different levels of prestige, rank, position, distribution of the governing and the governed, etc.), 3) professional stratification (different levels of education, functions, professional prestige, distribution managers and subordinates). Social inequality is the main determinant of social stratification and is influenced by various social, political, economic and professional factors. ${ }^{5}$

Social class implies a shared lifestyle based on social factors like occupation, education, income and wealth. According to Giddens, there are three classes in contemporary society: upper class (the wealthy, entrepreneurs, industrialists and top layer of managers, who own or directly control the means of production), the middle class (which includes the majority of white collar workers and specialists) and the working class ("blue-collars" or people engaged in manual labour). Giddens notes that in some industrialized countries such as France and Japan, an important role is assigned to the fourth class, i.e. peasants, who are engaged in traditional agricultural production. In the third world, peasants still constitute the largest class. ${ }^{6}$

Literature review and previous research on class structure shows that there are various methodological approaches for measuring the middle class in different countries. We will try to compare the methodological approaches

\footnotetext{
${ }^{1}$ A. Giddens, Социология (Москва: УРCC, 2005).

2 T. Shortell, "Weber's Theory of Social Class," Brooklynsoc, accessed November 25, 2019, http://www.brooklynsoc.org/courses/43.1/weber.html.

${ }^{3}$ P. Sorokin, Social and Cultural Mobility (Glencoe, IL: Free Press, 1959), 11.

${ }^{4}$ GIDDENS, Социология.

${ }^{5}$ A. TARKhnishvili, and L. Tarkhnishvili, "Middle Class: Definition, Role and Development," Global Journal of Human Social Science Sociology \& Culture 13, no. 7 (2013): 21-31.

${ }^{6}$ Giddens, Социология.
} 
for measuring the middle class in USA and Russia. According to Steven Pressman, in USA three methodological approaches for measuring the middle class were identified: 1) based on the annual household income, 2) based on the analysis of income earned by three middle quintiles, and 3) based on the level of education. All three approaches have limitations. Under the first one, there are no unique criteria and scale for determining the level of annual income appropriate for the middle class. As regards the second approach, it allows us to calculate the amount of income earned by the middle class instead of the size of the middle class. The limitation of the third approach is that many families with a high level of education but low level of income will be considered as middle class, and other families with a lower level of education but a high level of income will not be included in the middle class. ${ }^{7}$

The literature review done by some researchers on the Russian middle class shows also several methodological approaches for measuring the middle class, such as the ones: 1) based on the respondents' perception of their affordability to buy things to satisfy their needs, 2) based on integrated indicators (level of income, wealth, education, self-identification), and 3) based on market economy approach (level of consumption and lifestyle). ${ }^{8}$ In the first case, the main criteria for determining the middle class is the level of affordability of respondents to buy things according to their needs. Thus, the middle class includes the part of the population that has sufficient income for their basic needs and can obtain even more expensive items. Based on these criteria, in $2001,27 \%$ of the population could be considered as the middle class in Russia. In 2010, the share of the population that has income enough for food and clothes increased to more than half. ${ }^{9}$ The second methodological approach for measuring the middle class in Russia is based on the use of integrated indicators. The Institute of Sociology of the Russian Academy of Sciences used the following parameters to measure the middle class in 2006: the level of income, wealth, education, and self-identification. The research found that the middle class constitutes $20-22 \%$ of the economically

${ }^{7}$ S. Pressman, "Defining and Measuring the Middle Class," Working Paper 7, American Institute for Economic research, August 2015, 3-5, accessed November 26, 2018, https://www. aier.org/sites/default/files/Files/Documents/Standard/WP007-Middle\%20Class.pdf.

${ }^{8}$ А. СоболЕВ, “Дифференциация подходов к исследованию среднего класса в стратификационной модели современного российского общества. Автореферат на соискание степени кандидата социологических наук" (PhD diss., Russian Academy of Sciences, 2013), accessed November 26, 2019, http://www.dissercat.com/content/differentsiatsiya-podkhodov-kissledovaniyu-srednego-klassa-v-stratifikatsionnoi-modeli-sovr.

${ }^{9}$ Ibid., 3. 
active population. ${ }^{10}$ The third methodological approach is based on the market economy approach (a comprehensive analysis of lifestyle and level of consumption of respondents). An example in this context is the research conducted by the Expert magazine and the company Comcom. ${ }^{11}$ The following criteria were used to determine the middle class: customs and traditions of the country, lifestyle, spiritual values, education, freedom (both personal and as consumers), ownership of means of production, size and structure of expenditures, revenues and salary. The research concluded that more than $90 \%$ of the population constitute the lower class, $1 \%$ belong to the upper class, and up to $3-5 \%$ of the population forms the middle class. The limitation of this methodological approach is the large number of indicators that can influence the group size.

Based on the analysis of the above-mentioned methodological approaches, as well as other literature sources, ${ }^{12}$ we concluded that a comprehensive approach is necessary when measuring the middle class, one which would include several parameters, such as: the socio-occupational status, the level of education and level of wellbeing.

The main objective of our research was to study the level of social stratification in Moldova and to identify the premises for forming the middle class in the society the under economic and political transformation.

The main tools used for data collection were interviews and expert analysis. The research sample consisted of 1,179 non-randomly selected people aged 18-65 years (proportional odds) throughout the Republic of Moldova. The research was conducted in the period from June to September 2016.

\footnotetext{
${ }^{10}$ Ibid., 5.

${ }^{11}$ Ibid., 9-11.

${ }^{12}$ B. BARBER, Social Stratification. A Comparative Analysis of Structure and Process (New York: Harcourt, 2011); R. BendiX and S.M. LiPSET, eds., Class, Status, and Power (New York: Free Press, 1966); T. CLARK and S. M. LIPSET, “Are Social Classes Dying?” International Sociology 6, no. 4 (1991): 397-410; M. Dogan, "Status Incongruence in Advanced Societies," SocietàMutamentoPolitica 2, no. 3 (2011): 285-94; H. DoMAŃSKI, Z. SAWIŃSKI, and K. SŁOMCZYŃSKI, Sociological Tools Measuring Occupations. New Classification and Scales (Warsaw: Ifis Publishers 2009); European Social Survey, How to Ascertain the Socio-Structural Position of the Individual in Society. European Social Survey Core Questionnaire, accessed November 25, 2018, https://www.europeansocialsurvey.org/docs/methodology/core_ess_questionnaire/ESS_core_ques tionnaire_measuring_social_structure.pdf; RAZuMkov CENTRE, Middle class in Ukraine: Identification Criteria. Expert Assessments, Citizens' Perceptions and Self-Identification (Kyiv: Zapovit, 2014), accessed November 25, 2018, http://fnst.org/sites/default/files/uploads/2016/08/02/1416 488152file1.pdf.
} 


\section{THE MAIN FINDINGS OF OUR RESEARCH}

Respondents' social status. The Moldovan society is distributed across 6 social strata in respect of their socio-occupational status, level of education and wellbeing. The first stratum includes $18 \%$ of the total respondents. More than $90 \%$ in this category are unskilled or skilled workers, and the highest level of education of $98 \%$ of them is vocational. $100 \%$ do not own a car. The second stratum includes $13 \%$ of the total respondents. $76 \%$ in this group are unskilled or skilled workers, the highest level of education for $98 \%$ of them is vocational, $25 \%$ of them do not have a car, and $75 \%$ have a car older than 10 years. The third stratum encompasses $15 \%$ of the total respondents. More than half of them are specialists with a medium level of qualifications, $100 \%$ have a medium level of education, two thirds do not own a car and a third of them have a car that is older than 10 years. The fourth stratum includes $61 \%$ of workers in the service sector and specialists with a medium level of qualification, as well as $13 \%$ of specialists with a high level of qualification. One in four respondents has a high level of education, $100 \%$ of them have cars newer than 10 years. The fifth stratum includes $82 \%$ of specialists with high level of qualification and top managers, $86 \%$ of the respondents have a high level of education, $71 \%$ of them do not have a car or have a car that is older than 10 years. As regards the sixth stratum, 57\% of the respondents are specialists with a high level of education and top managers, $100 \%$ present a high level of education, $86 \%$ do not have a car or have a car older than 10 years.

The analysis of the strata in respect of occupation, education and wellbeing shows status inconsistency and a low level of status crystallisation in all six strata. The respondents in strata 1 and 2 have a low socio-occupational status, medium education level and low welfare level. Respondents from stratum 3 have a medium socio-occupational status, medium level of education and low level of welfare. Respondents from stratum 4 have a medium socio-occupational status, medium education level and medium to high level of welfare. Respondents in strata 5 and 6 have a high level of socio-occupational status, high level of education and low welfare level (see Table 1). 
Table 1: Social strata characteristics as the function of socio-occupational status, education and welfare

\begin{tabular}{|c|c|c|c|c|c|c|c|c|c|}
\hline & \multicolumn{3}{|c|}{$\begin{array}{c}\text { Socio-occupational } \\
\text { status }\end{array}$} & \multicolumn{3}{c|}{ Level of education } & \multicolumn{3}{c|}{ Level of welfare } \\
\hline Strata & low & medium & high & low & medium & high & low & medium & high \\
\hline Stratum 1 & $\mathrm{X}$ & & & & $\mathrm{X}$ & & $\mathrm{X}$ & & \\
\hline Stratum 2 & $\mathrm{X}$ & & & & $\mathrm{X}$ & & $\mathrm{X}$ & & \\
\hline Stratum 3 & & $\mathrm{X}$ & & & $\mathrm{X}$ & & $\mathrm{X}$ & & \\
\hline Stratum 4 & & $\mathrm{X}$ & & & $\mathrm{X}$ & & & & $\mathrm{X}$ \\
\hline Stratum 5 & & & $\mathrm{X}$ & & & $\mathrm{X}$ & $\mathrm{X}$ & & \\
\hline Stratum 6 & & & $\mathrm{X}$ & & & $\mathrm{X}$ & $\mathrm{X}$ & & \\
\hline
\end{tabular}

Based on the status inconsistency and the low level of status crystallisation we can conclude that the process of classes formation is just at the initial stage in Moldova. Our analysis of social stratification in terms of middle-class criteria: high socio-occupational status, high education level, high level of welfare shows some prospects of formation of the middle class in the strata 4, 5 and 6 . The respondents in strata 5 and 6 are characterized by a high socio-occupational level, high education level and low welfare level. The respondents in strata 4 are characterized by a medium socio-occupational level, medium education level and from medium to high welfare level.

Factors influencing social status. According to the research, the social status of respondents depends on certain personal characteristics (level of education, socio- occupational status, income, socio-occupational status in the beginning of professional career); parents' social status (socio-occupational status and level of education), and the social status of the respondent's partner (socio-occupational status and level of education).

With regard to personal characteristics, the research shows a significant statistical association between the following factors: a) the level of education of respondents and their socio-occupational status (Cramer's $\mathrm{V}=$ $0.139)$, b) the socio-occupational status of respondents and the monthly income per each family member (Cramer's $\mathrm{V}=0.218$ ), c) the level of education of respondents and income per each family member (Cramer's $\mathrm{V}=$ $0.192)$, d) the socio-occupational status of respondents in the present and 
their socio-occupational status when they had their first job (Cramer's V = 0.669). However, the intensity of the relationship between the level of education and the socio-occupational status, socio-occupational status and income is poor. This fact shows that the social transformations that took place in the Moldovan society broke the logical link between the most important factors influencing the social status, like level of education and sociooccupational status, level of education and income, socio-occupational status and income. This also means that the level of education in Moldova does not always result in a high socio-occupational status and therefore a high living standard. Given the conditions of the society with poor quality of education, high corruption, shadow economy, professional promotion based on relations and affiliation with different parties, the motivational mechanism of social stratification becomes dysfunctional. However, according to our research, the intensity of correlation between the socio-occupational status of the respondents in their first job and their current socio-occupational status is medium to high, which demonstrates, on the one hand, the importance of sociooccupational status in the first job for career advancement and, on the other, argues for a reduced level of professional mobility because the economy is underdeveloped, jobs are limited and unemployment rate is high.

According to our study, there is a statistically significant correlation between the following factors: a) the socio-occupational status of respondents and the socio-occupational status of their parents (Cramer's $\mathrm{V}=0.187$ ), and b) the level of education of respondents and the level of education of their parents (Cramer's $\mathrm{V}=0.266)$. However, the intensity is also low.

Our research has confirmed a statistically significant correlation between a) the socio-occupational status of respondents and the socio-occupational status of their partners (Cramer's $\mathrm{V}=0.231$ ), and $\mathrm{b}$ ) the level of education of respondents and the level of education of their partners (Cramer's $\mathrm{V}=$ 0.509). However, the intensity of the correlation between the sociooccupational status of respondents and the socio-occupational status of their partners is low. As for the correlation between the level of education of respondents and their partners' level of education, the intensity is medium to high. This confirms once again that research in social stratification should be household based rather than person based.

Respondents' working status. As per our research, $80 \%$ of the respondents are employed and a fifth of them are not; the share of the unemployed individuals is higher in rural areas, in the group aged $18-24$, as well as in the group of respondents with low level of education. 
To overcome economic problems, over a third of the respondents work overtime (more than 41 hours per week) in their workplace or have several jobs at the same time, and every tenth person is working part- or full-time abroad. The share of those working abroad or overtime is higher in stratum 4 ; the share of those working part-time is higher in stratum 1. Part-time employment is characteristic for women, elderly people, students, and selfemployed individuals.

Every second employed respondent works in a public institution, $43 \%$ work in private establishments, and every tenth in the informal sector or in the household. As regards the social strata, two thirds of the respondents in strata 5 and 6 are employed in the public sector and more than half of those in stratum 4 in the private sector. The share of the respondents who are employed on a permanent basis and receive social insurance, paid sick leave or annual leave is higher in the public sector than in the private one. As a result, the share of the respondents receiving social security benefits is higher in strata 5 and 6 and lower in strata 1-4. The share of the respondents that have subordinated employees is also higher in strata 5-6.

The level of adaptability to new conditions (no fear of job loss or unemployment or change of the occupation) is higher in strata 4-5 and lower in strata 1-3. About a third of the respondents have a previous experience of unemployment or are currently unemployed. The share of those who have experienced unemployment is higher among people with a low level of education, in rural areas, as well as in strata 1-3.

Respondents' income. Over $60 \%$ of the respondents have a monthly income per a family member of less than 2,000 lei, which also is below the subsistence minimum for 2015 (1,734 lei) or slightly above the subsistence minimum. Every third respondent indicated a monthly income per a family member between 2001 and 5000 lei and 7\% reported the amount of more than 5,000 lei. The share of respondents with monthly income per a family member higher than 2,500 lei is greater in strata 4, 5,6 and lower in strata 1, 2 and 3. More than half of the respondents said that their income is much lower than their needs, every fourth respondent said that their income is slightly lower than their needs, and every fifth indicated that their income is equal to or even higher than their needs. The share of people with income much lower than their needs is higher in rural areas, in small towns, among the respondents with a low level of education, as well as among the respondents in strata 1-3. About $90 \%$ of the respondents from strata 1, 2, 3, 5, 6 stated that their salary, pension, and allowances were the main source of 
their income. In the case of stratum $4,75 \%$ of the respondents mentioned salary, pension or scholarships the main source of income, and $25 \%$ reported self-employment, rental of property, or remittances.

More than $80 \%$ of the respondents have some property. The share of those who do not own any property is higher in strata 1 . More than two thirds of the respondents who own properties mentioned that if they sold all their property and pay all debts, they would still be left with some savings.

According to the research, the purchasing capacity of the respondents is quite low. More than two thirds of the total respondents could not afford to support financially a child to study abroad, and more than half of the respondents cannot afford trips abroad, $90 \%$ of respondents would not be able to buy an apartment, $83 \%$ would not be able to buy a car, $46 \%$ would not be able to buy technological items for the household. The share of those who could afford to buy these things is higher in strata 4, 5, 6 and lower in strata $1,2,3$.

Self-identification with the social class. Most of the respondents are not aware of social class characteristics and identified themselves with the class which in their view would better correspond to their social position in the community, neighbourhood, and family. Thus, about $82 \%$ identified themselves with positions that correspond to the lower middle class $(43 \%)$, the core middle class $(27 \%)$ or the upper middle class $(12 \%)$, and only $18 \%$ identified themselves with the lower class. The share of respondents who identified themselves with the upper middle class is higher among the respondents aged 18-24 years; the share of the respondents who identified themselves with the lower class is higher among persons aged 65 years and older.

Our analysis of the results of self-identification per social strata shows that the percentage of respondents who identified themselves with the lower class or lower middle class is higher in stratum 1; the percentage of respondents who identified themselves with the core middle class is higher in strata 2 and 3; the percentage of respondents who identified themselves with the upper middle class is higher in strata 4,5 and 6.

Most of the respondents believe that in Moldova there are large or very large conflicts between the class of politicians and other citizens, between people from the top and bottom of society and the bottom of the society, between the rich and the poor.

According to the majority of respondents, the factors that contribute to the upward movement of people along the social ladder and their location in upper classes (elite circles) are the following: 1) relationships, 2) money, 
welfare, 3) descent — rich families, 4) studies and 5) political connections or party. Our analysis of the respondents' opinions in stratum 6 (this stratum includes a large number of leaders/top managers), highlighted three basic factors that contribute to the promotion of people in the upper strata: 1) relationships, 2) money, welfare, and 3) political connections or party.

Health status. Although more than two thirds of the respondents declared their health status to be good and very good, over $50 \%$ of them said they would feel not really good or really bad if they were in the situation to carry something heavy along several floors. The share of people who would feel not very well or really bad is higher among the respondents aged over 45 years, among those with a low level of education, as well as in the lower strata $(1,2,3)$.

More than $40 \%$ of respondents (in particular those with a high level of education, from the urban areas or from the upper strata) felt hurried, always or frequently pressurised at their workplace in the past month. Every fourth respondent (especially in rural areas, where education is low) felt always or frequently discouraged. Every fourth person indicated some constraints at their workplace, and they could not finish the planned activities because of their psycho-emotional state.

About $80 \%$ of the respondents indicated that they do not smoke as opposed to about $20 \%$ who declared to be smokers. The proportion of smokers is higher in rural areas, in the 18-24 age group with a low level of education. About two thirds of smokers consume more than 11 cigarettes a day.

More than $50 \%$ of the respondents have a normal body mass index and each third respondent is overweight or obese. The share of overweight or obese respondents is higher among men, people older than 45 years, those who live in urban areas, and the respondents from strata 1, 2 and 3.

More than half of the respondents reported that they encountered health problems in the last 12 months. The most frequently reported health problems include back pain, high blood pressure, migraine, or allergies. The most frequently reported health problem in the lower strata are back pain and high blood pressure. The most frequently reported health problem in the upper strata are allergies, migraine and blood circulation.

More than $50 \%$ of the respondents visited the doctor in recent months. Every second of them saw the doctor more than twice. The share of the respondents who saw the doctor more than twice is higher among those with low education and those older than 45 years. 
There are many respondents that eat unhealthy food frequently; they often use white bread, toasted products, sweets, cakes and - quite rarely - vegetables and fruit. The share of men consuming alcoholic beverages (beer, wine, brandy, and cognac) quite frequently (every day or at least once a week) is quite high.

Working conditions. More than half of the respondents reported unhealthy working conditions: working overtime, noise, dust, gases, or time pressure and unhealthy competition. More than $40 \%$ of the respondents said they had a hard, physical job or unhealthy competition at that their workplace.

\section{CONCLUSIONS}

The results of our research demonstrate that the formation of the middle class in Moldova faces the following barriers:

a) low labour cost leading to increased poverty, also among skilled workers;

b) reduced opportunities and less social mobility among people from lower strata preventing them from advancing to higher strata of society;

c) failure of the motivational mechanism to increase human, social and cultural capital;

d) devaluation of university education as a key factor for advancing along the occupational scale, as well as for income increase;

e) increased influence of the shadow economy, leading to illegal jobs, limited access to social insurance/social benefits and reduced opportunities for legal employment;

f) underdeveloped small and medium enterprises;

g) crisis of legal system, which leads to violations of law, selective justice and imperfect legislation; and

h) a high level of corruption in all structures of power and fake attempts to combat corruption, leading to a non-transparent approval of political and economic decisions.

The formation of the Moldovan middle class would be possible if based on strata $4,5,6$, which are characterized by a high level of education and a high socio-occupational status, if the following conditions were met:

- developing wage policies,

- reforming tax policies by promoting progressive taxation of income,

- ensuring equitable distribution of wages according to the work done,

- eliminating corruption in structures of state authority, 
- improving legislation,

- ensuring public access to decision-making processes,

- creating favourable conditions for the development of small and mediumsized enterprises,

- developing a transparent environment for the market economy,

- guaranteeing equal opportunities to ensure access to education and health services.

Population values and the level of economic consciousness are also of special importance in the process of middle-class formation. Orientation toward pragmatic values of the market economy, increasing growth trends in human, social and cultural capital can contribute to an enhanced involvement of the Moldovan society in different spheres of economy.

\section{BIBLIOGRAPHY}

BARBER, Bernard. Social Stratification. A Comparative Analysis of Structure and Process. New York: Harcourt, 2011.

Bendix, Reinhard, and Seymour M. LiPSET, eds. Class, Status, and Power. New York: Free Press, 1966.

Clark, Terry N., and Seymour M. LiPSET. “Are Social Classes Dying?” International Sociology 6, no. 4 (1991): 397-410.

Dogan, Mattei. Status Incongruence in Advanced Societies. SocietàMutamentoPolitica 2, no. 3 (2011): 285-94. https://doi.org/10.13128/SMP-10332.

Domański, Henryk, Zbigniew SAwIŃSKi, and Kazimierz SŁomcZYŃSKi. Sociological Tools Measuring Occupations. New Classification and Scales. Warsaw: Ifis Publishers, 2009.

Fulton, Diane, David Furman, and Nikki Finlay. "A Longitudinal Study of the Middle Class: Growth, Size and Marketing Strategies." Research in Business and Economics Journal 10 (October 2014). https://www.aabri.com/manuscripts/142031.pdf.

Giddens, Anthony. Соииология. Москва: УРСC, 2005.

European Social Survey. How to Ascertain the Socio-Structural Position of the Individual in Society. European Social Survey Core Questionnaire. Accessed November 25, 2018. https://www.europeansocialsurvey.org/docs/methodology/core_ess_questionnaire/ESS_core_ questionnaire_measuring_social_structure.pdf.

RAZumkov Centre. Middle class in Ukraine: Identification Criteria. Expert Assessments, Citizens' Perceptions and Self-Identification. Kyiv: Zapovit, 2014. Accessed November 25, 2018. http://fnst.org/sites/default/files/uploads/2016/08/02/1416488152file1.pdf.

PARsons, Talcott. Essays in Sociological Theory: Pure and Applied, 166. Glencoe, IL: Free Press, 1949.

Pressman, Steven. "Defining and Measuring the Middle Class." Working Paper 7. American Institute for Economic Research, August 2015. Accessed November 26, 2018. https://www. aier.org/wp-content/uploads/2016/10/WP007-Middle-Class.pdf. 
RAdulEȚ, Ani. "Stratificarea sociala." Revista Transilvană de Ştiinţe Ale Comunicari 14, no. 3 (2011): 93-104.

SHAH, Shelly. "Social Stratification: Meaning, Origin, Development and other Details." Sociology Discussion. Accessed November 26, 2016. http://www.sociologydiscussion.com/socialstratification/social-stratification-meaning-origin-development-and-other-details/2260.

SHORTElL, Timothy. "Weber's Theory of Social Class." Brooklynsoc. Accessed November 25, 2019. http://www.brooklynsoc.org/courses/43.1/weber.html.

Sorokin, Pitirim. Social and Cultural Mobility. Glencoe, IL: Free Press, 1959.

Tarkhnishvili, Anna, and Levan TARKhnishvili. "Middle Class: Definition, Role and Development." Global Journal of Human Social Science Sociology \& Culture 13, no. 7 (2013): 21-31.

АвРААмОВА, Елена. “Формирование среднего класса в России: определение, методология, количественные оценки." Общественные Науки и Современность [AVRAAMOVA, Yelena. "Formirovaniye srednego klassa v Rossii: opredeleniye, metodologiya, kolichestvennyye otsenki." Obshchestvennyye Nauki i Sovremennost'], no. 1 (2002). Accessed November 25, 2016. http://ecsocman.hse.ru/data/799/893/1231/2.pdf.

БАКштАновСКий, Владимир, and Юрий Согомонов. Этос среднего класса: Нормативная модель и отечественные реалии. Тюмень: Центр прикладной этики, 2000. [BAKSHTANOVSKIY, Vladimir, and Yuriy Sogomonov. Etos srednego klassa: Normativnaya model' iotechestvennyye realii. Tyumen': Tsentr prikladnoy etiki, 2000.] Accessed November 25, 2016. http://www.tyuiu.ru/wp-content/uploads/2015/10/Bakshtanovskij-V.I.-Sogomonov-YU. V.-Etos-srednego-klassa.pdf.

СоБолев, Алексей. “Дифференциация подходов к исследованию среднего класса в стратификационной модели современного российского общества. Автореферат на соискание степени кандидата социологических наук." [SOBOLEV, Aleksey. "Differentsiatsiya podkhodov $\mathrm{k}$ issledovaniyu srednego klassa $\mathrm{v}$ stratifikatsionnoy modeli sovremennogo rossiyskogo obshchestva. Avtoreferat na soiskaniye stepeni kandidata sotsiologicheskikh nauk.”] Phd diss., Russian Academy of Sciences, 2013. Accessed November 26, 2016. http://www. dissercat.com/content/differentsiatsiya-podkhodov-k-issledovaniyu-srednego-klassa-v-stratifi katsionnoi-modeli-sovr.

\section{MIDDLE-CLASS FORMATIVE FACTORS \\ IN THE MOLDOVAN CONTEMPORARY SOCIETY}

\section{Summary}

The sociological research on the formation of middle class in the Republic of Moldova, conducted from June to September 2016 by the researchers from the Sociology and Social Psychology Centre, shows that the Moldovan society is stratified into 6 levels that is diversified by the socio-professional status, education and the level of wellbeing. Status inconsistency and the low level of status crystallisation are characteristics for all the strata within the conditions of dysfunctionality of the logical chain: education - social and occupational status - welfare. The analysis of social strata in terms of middle class criteria (high socio-occupational status, high education level, high level of welfare) shows some prospects for the formation of middle class in the upper strata under the following conditions: development a salary policy, reforming tax policies by promoting the progressive taxation, elimination of corruption in structures of power, improving 
legislation, assuring proper conditions to enable the population to access educational and health services.

Key words: social stratification; social class; socio-occupational status; social self-identification; middle class.

\section{CZYNNIKI FORMACYJNE KLASY ŚREDNIEJ WE WSPÓŁCZESNYM SPOŁECZEŃSTWIE MOŁDAWSKIM}

\section{Streszczenie}

Badania socjologiczne na temat formacji klasy średniej w Republice Mołdawii, przeprowadzone w okresie od czerwca do września 2016 r. przez naukowców z Centrum Socjologii i Psychologii Społecznej, pokazują, że społeczeństwo jest podzielone na 6 różnych warstw społecznych według statusu społeczno-zawodowego, poziomu wykształcenia i poziomu dobrobytu. Niespójność statusu i niski poziom krystalizacji statusu są cechami charakterystycznymi wszystkich warstw w warunkach dysfunkcjonalności łańcucha logicznego: edukacja - status społecznozawodowy - dobrobyt. Analiza warstw społecznych pod kątem kryteriów klasy średniej: wysoki status społeczno-zawodowy, wysoki poziom wykształcenia, wysoki poziom dobrobytu, pokazuje pewne perspektywy kształtowania się klasy średniej w wyższych warstwach w następujących warunkach: opracowanie polityki płac, reforma polityk podatkowych poprzez promowanie progresywnego opodatkowania dochodów, eliminacja korupcji w strukturach władzy, poprawa ustawodawstwa, gwarancja odpowiednich warunków w celu zapewnienia dostępu do edukacji i usług zdrowotnych.

Słowa kluczowe: rozwarstwienie społeczne; klasa społeczna; status społeczno-zawodowy; samoidentyfikacja społeczna; klasa średnia. 